\title{
ANALYSIS OF RELIGIOUS SATIRE IN P'BITEK'S SONG OF LAWINO
}

\author{
Dr. C. A. Adetuyi ${ }^{1}$, Dr. C. A. Patrick ${ }^{2}$ \\ Department of Languages, College of Humanities, \\ Samuel Adegboyega University, Ogwa, Edo State. ${ }^{1,2}$ \\ dradetuyi@gmail.com
}

\begin{abstract}
This paper focuses on the analysis of religious satire in Song of Lawino. The study occasionally refers to Okot's life history and ideological inclinations and the review of related literature giveng background information that clarifies Okot p'Bitek's writing as a product of a rich Acholi oral tradition. While a lot has been written on Okot's creative works, little attention has been given to the use of satire. The study therefore, identifies and evaluates Okot's use of satire in Song of Lawino determines the use of language to achieve satire in the text, and discusses how the author uses satire as a tool to share ideas and opinions on religious perspectives in the society. This study treats satire as the humorous criticism of human weaknesses and foibles and uses this parameter to identify it in the Song of Lawino. This is to throw light on the creative works of Okot's and highlight circumstances that may have shaped him into a satirist. The upshot of all these is that the songs are appropriately contextualized with the ultimate finding that satire is an indigenous African phenomenon amply and ably deployed in Okot's art.
\end{abstract}

Keywords: satire, humour, parody, force, travesty

\section{INTRODUCTION}

Satire is a technique employed by writers to expose and criticize foolishness or societal ills involving an individual or a society. Apart from playing the role of an entertainer, the artist uses his artistic creation to instill truth into people's consciousness by using humour to ridicule the victim(s).

The literary artist is known to have used satire from the beginning of literary history. The Greek and the Romans extensively employed it as a weapon of attack on their respective societies as far back as the $5^{\text {th }}$ Century. The Poet, Aeschylus for example, is said to be the first Greek literary artist during this period. Among the ancient Roams, there were such names as Horace, Juvenal, etc. whose satiric works and ideas have continued to sharpen and influence the minds of contemporary satirists (Olaniyan, 2015).

Bruun (2007) writes that Africa has a short history of satire. His statement does not take into cognizance the fact that satire existed in traditional African society as evident in the oral literature of various African communities. Roscoe's comment also implies that satire is a recent "innovation" in Africa. This paper reveals that Africa is rich in satire, and that it existed in the oral literature of African communities, and in written literature as exemplified by Okot's songs.

Moy and Hess(2007) make two statements that this study responds to. First he says,

as an essayist, I think Okot is hopeless in all his writings and public addresses; Okot has been saying the same thing since 1965 - that we must not ape the white man, that we must not 
lose our cultural identity. The second statement is, "you see, it was great to read Okot in the sixties. Everybody, including the politicians, was calling for "complete independence".

In essence, Bruunhas relegated Okot's literary works to the abyss; apparently he does not consider them relevant in this era. This study differs with Bruun's views in the sense that, satire makes Okot's poetry relevant to our contemporary societies. He discusses important issues that are still relevant today.

This paper also takes into cognizance the academic contributions of several literary scholars who have critically appreciated Okot's creative works. However, these scholars have rightfully identified the existence of satire in the creative works of Okot, but they have not given it a qualitative and quantitative coverage. This study fills this gap because it entails a detailed study of satire in Okot's songs. It goes beyond identifying satire by mentioning its targets, and how they are satirized, it foregrounds the stylistic devices that lead to satire. This concentration on stylistic devices makes the study literary and not just a treatise on religions and religious leaders.

\section{METHODS}

\section{Functions of satire}

Satire is an interdisciplinary element that is used both in disciplines of media and literature. According to Khalayi (2014):

humour and satire occupy a prominent position within the aesthetic conditions of contemporary culture, both in terms of literary arts and popular media.

Even though this paper is more concerned about the role of satire in literature, it is worth explaining the other functions of satire.

\section{Satire as a literary device}

As aforementioned, this study is concerned about the prominent position which satire and humour occupies within the aesthetic conditions of contemporary culture in terms of literary arts. It is worth clarifying that satire, in terms of literary arts, is a literary device. In addition to other literary devices, satire is an important device in literature. Literary devices are often referred to as figures of speech; therefore, satire should also be regarded as a figure of speech that writers include in their writing to enhance creativity. Literary language is open to various interpretations because connotations differ from person to person. Satirists deserve to be regarded as artistically talented because of their ability to employ satire effectively.

\section{Satire in popular culture}

Many works that are written from socio-political standpoints are known to be popular culture. Greene (2009) explains that "traditional social values, morals and structure are often mocked and ridiculed to highlight their apparent foolishness". Greene (2009) further clarifies that "while much of the time ridicule and mocking is in playful 
manner, these social and political commentaries function as powerful and ideologically infused discursive strategies in the construction of meaningful rhetorical action".

According to Mukerji and Schudson (cited in Khalayi, 2014), popular culture "includes folk or popular beliefs, practices and objects generated from political and commercial centres". Readable objects, whether they are written or visual materials that are available traditions of interpretation and criticism, are classified and perceived to be part of popular culture (Khalayi, 2014).

Okot' P Btek'ssatire appears to fit the description of an object of popular culture because his articles are readable objects that are written from socio-political standpoints, which are available traditions of interpretation and criticism, hence making his columns an example of popular culture.

According to Khalayi (2014), "popular culture and popular literature is seen as what is socially acceptable among the masses", it ranges from "films to the internet, and then to the creative newspaper space".

\section{Political Satire}

As a type of entertainment-oriented political content that aims at criticizing politics and revealing violations of social norms in an implicit and playful way, political satire has drawn scholarly attention in terms of whether it could play a significant role in facilitating a more engaged public. Much academic research has examined the potential impact of exposure to political satire on behavioral engagement. However, there are inconsistent results regarding the influence of political satire on political participation.

Some researchers have documented that exposure to political satire such as latenight comedy could foster democratic engagement (Cao \& Brewer, 2008; Moy, Xenos, \& Hess, 2007), while others have suggested that political satire may undermine participation because it contributes to "a sense of alienation from the political process" (Baumgartner \& Morris, 2009) and it intends to entertain rather than inform citizens. (Prior, 2011)

\section{FINDINGS}

\section{Satire on Religion and Religious Leaders in Song of Lawino}

Religion is often linked to purity, morality, justice, truth, fairness and love. It is associated with good, and evil in its antithesis. Religious leaders and the adherents of a certain religion are often criticized especially when they fail to live up to the standards of their religion.

In Song of Lawino, Christian religion and religious leaders are criticized. Lawino is the satiric tool. Okot's opinion on the Christian religion is elucidated in essays onAfrican Religion in Western Scholarship and in Religion of the Central Luo. His opinion in these texts also pervades Song of Lawino. Intolerant priests, rulers and teachers of religion are criticized in the Song.

Lawino describes their response to questions asked by converts in humorous language. She says that the nun responds to questions "by screaming fiercely like a 
wounded buffalo" (131). This description of a nun screaming like a wounded buffalo is indeed humorous, especially when one considers that the cause of their harsh reactions are the innocent questions asked by converts. Her reaction is contrary to the teaching of the Christian faith, because tolerance is one of the virtues of Christianity.

The black teacher responds to questions by saying that asking too many question benefit only Martin Luther and the stupid, stubborn protestants (131). The priest, on the other hand, quarrels and his goatee beard shakes furiously (132). The priests and teachers of religion present a pious appearance especially when conducting religious duties. But in reality, they display tolerance especially to the new converts. The ironic exposure of religious leaders is a satire on intolerance.

In the same vein, the candid exposure of the reaction of the religious leaders is done in a series of similes like, "fierce like wound buffalo she screams" (131) and "he quarrels and his goatee beard shakes" (132). This description is also a criticism of their behavior. In this regard, irony and similes are used to evoke humour and to reinforce criticism.

Ogola (2009) observes that:

Some important questions the black of colonial period ask themselves because the white missionaries did not want to face such stupid questions from the heathens. (7)

Lawino says that the religious leaders often considered the converts' questions as nonsensical and silly (132). Her observation tally with Higg's comment in the sense that she acknowledges that she has questions concerning the teachings she got in the catechism classes. Yet, the teachers, nuns and priests did not want to answer them because they associate the questions with rebellion and lack of faith (132).

Religious leaders who engaged in bribery are castigated by Lawino. She exposes them by giving a detailed account of their deeds. For example, she says that the children who did not ask questions are bestowed with gifts and favours like riding in the priest's car with words of 'appreciation' (133) The 'favour' given to the 'obedient' children are indeed a form of bribery, and also a method of blackmailing the children so that they do not ask questions. It is ironic that the religious leaders who are highly esteemed in the society engage in acts of bribery. The conduct of these religious leaders is contrary to the tenets of the Christian religion.

Religious leaders who use religion for their personal gain are also criticized. Lawino says that a girl who wants to be baptized gained approval by engaging inhard labour. She says:

\author{
I refuse to join \\ The Protestant catechist class, \\ Because I did not want \\ To become a house-girl, \\ I did not want \\ To become a slave \\ To a woman with whom \\ I may share a man
}


Oh how young girls

Labour to buy a name! (111)

From the quote, it is evident that the teachers of religion misuse their students several ways. For example, they are given household chores and they also engage in hard labour. These students do not perform these tasks willingly. On the contrary, the religious leaders are using their labour freely. Thestudents oblige to the demands of their teacher because students are expected to be obedient. These teachers of religion abuse the student-teacher relationship for their benefit. The also use their position to exploit the helpless students. However, one does not expect a teacher who teaches religion to behave in an erratic manner. This is because they are expected to be custodians and perpetrators of love, fairness and justice.

The study so far has focused on Okot's satire on hypocrisy, intolerance, bribery and misuse of position. On the other hand, he satirizes the tenets of the Christian religion. Okot's essays on African Religion in Western Scholarships and in Artist the Ruler, contain scathing attacks on the tenets of the Christian religion, and its adherents. Suffice is to say that although he discusses the Islamic religion in Artist the Ruler, the Christian religion occupies most ot his attention.

In Song of Lawino, the basic tenets of the Christian religion are satirized. The tenets are: the Holy Communion, baptism, the creation, their concepts of God, the miraculous birth of Jesus Christ and Christian prayers.

Lawino describes the Holy Communion using humour. She says:

The name of the man
Was Eliya
And he was calling people
To come and eat human flesh!
He puts little bits
In their hands
And they ate it up!
Then he took a cup,
He said
There was human blood
In the cup
And he gave it
To the people
To drink! (113-114)

Lawino's description ridicules and trivializes the Holy Communion. It portrays the ritual as incomprehensible and nonsensical. In essence, the humorous description destroy all the symbolic meaning associated with the bread and the wine in the communion service.

On the other hand, Lawino has presented herself as an adherent of the acholi culture. In this regard, mysticism and rituals are not strange to her. Indeed, she seems conversant with Acholi rituals (143-166) which look ridiculous to non-Acholis. Her reaction to the Holy Communion is not only ironic, but it indicates that she is intolerant 
to the beliefs of other people. Consequently, her intolerance is also the butt of criticism. Baptism is another tenet of the Christian faith that is satirized. Lawino parodies the baptismal names as exemplified by names such as Bene del a, Maria, Jekcon, Paraciko, Tome on, Iriko, Gulyemo, Medikijedekiand Gilrigoloyo (124-5). Indeed the manner in which she parodies the names is humorous. Irikoffor example means Eric and Gilirigoloyomeans Gregory. Lawino's parody on the names is not an end in itself, rather it is intended to mock and ridicule baptismal names.

Lawino also equates the baptismal names to old dusty tins thrown down from the roof tops (129). This are renown for noisy effects particularly when they are empty, old and rusty. They are not only capable of making noise but they are also useless because of the rust. She uses the metaphor to imply that the Christian baptismal names are useless, and meaningless. The baptism ritual too does not escape Lawino's wrath. She describes it as the day when Christians give their children meaningless names of white men after putting water on the heads of their children (129) questions:

Lawino exposes her doubt on the Christian creation story in a series of rhetorical

Where did he dig the clay

For mouding things?..

And the clay for moulding Earth?

From the mouth of which River?.

Where did the hunchback live?..

Where did the hunchback

Dig the clay for moulding things?

On he mouth of which River?

Where did he put the clay

To season overnight?...

On which rock

Did the Hunchback put the clay? (13-13)

Prior to the above rhetorical questions, Lawino describes how her mother made pots. She describes the process of selecting the raw materials and all the stages that a potter subjects the raw material before the finished product is attained. The questions ridicule and depict the creation story as nonsensical and incredible. The creation story is the target of criticism.

The concept of a single deity is satirized through a several rhetorical questions and the "hunchback":

\section{Where did the Hunchback live? \\ Where did the Hunchback dig? \\ Where did he stand? (13-13)}

The image used in the above quote means a hostile spirit that the Acholis believed caused hunchback. Nevertheless, in the context of Song of Lawino. It implies that the Christian God is equivalent to the malevolent spirit that causes hunchbacks. It creates the impression that the Christian God is a helpless, grotesque and pathetic being. 
Lawino is therefore using the image of the hunchback to mock the Christian concept of God.

Lawino also compares the miraculous birth of Christ to the Acholi customs with the intention of ridiculing it:

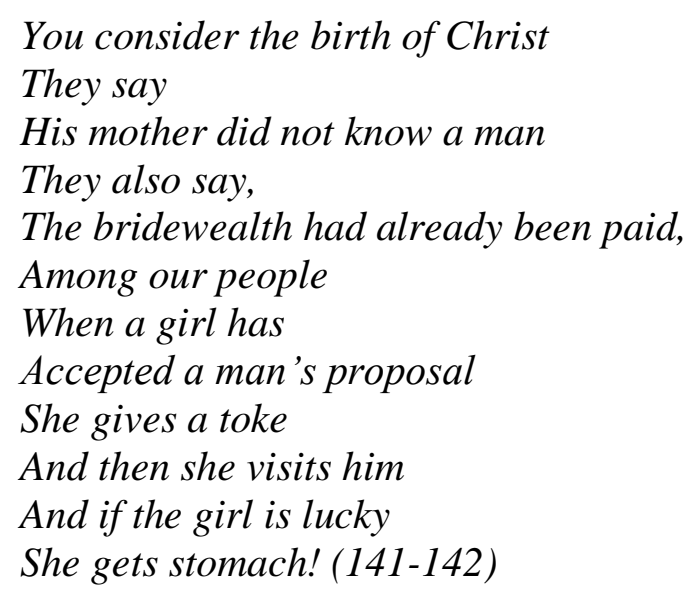

Lawino's comparison of the virgin birth of Christ and the Acholi culture is a satire on the Christian concept of the virgin birth of Christ. It also presents the Christian version of Christ's birth as incredible.

Apart from the issue of the virgin birth of Jesus Christ, the prayers that have to be chanted in either the Protestant service or during the evening classes also puzzle Lawino. She mocks the prayers using low burlesque as follows:

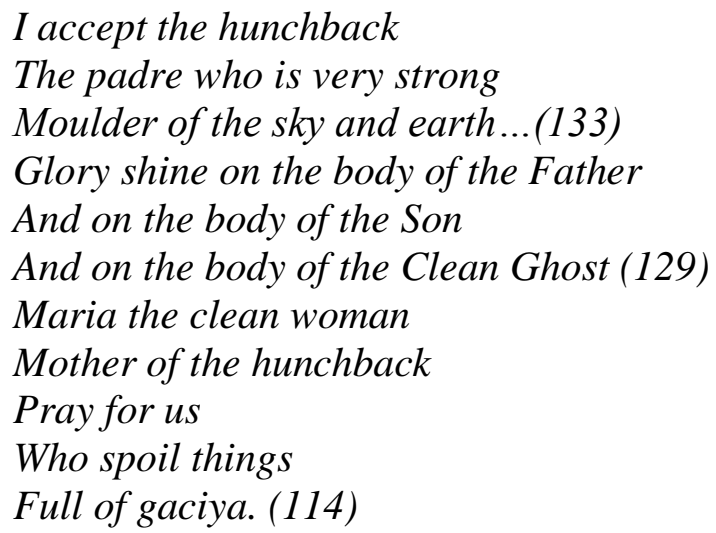

The original Christian version reads:

I believe in God the father who is almighty

Maker of heaven and earth glory be to the father

And to the son and to the Holy Spirit

Hail Mary mother of God

Pray for us sinners full of grace

Lawino's version not only defies the original but also ridicules its contents. For example, she changes 'maker of heaven and earth' to 'moulder of the sky and the earth'. On the other hand, 'Hail Mary, mother of God,' is changed to 'Maria, the clean woman, 
mother of the hunchback, pray for us'. The contents of the original are trivialized to the point where they look ridiculous and humorous.

In the same vein, Laiwno compares the Christian prayer session to 'shouting contests' (133). She states that during the prayer sessions, the teachers shout as if half mad and they shout back (133). She also compares the prayer sessions to recitals or music sessions where they sing like parrots (132) or recite like "yellow birds in the Lajanawara grass" (133). Parrots usually make sounds similar to what they have heard. On the other hand, the "Yellow birds" probably makes a lot of noise. When Lawino says that she recites prayers like the birds, she implies that she does not understand what she is reciting. Indeed, since the yellow bird and the parrot are noisy and incomprehensible, Lawino uses them as images to ridicule the Christian prayer session. The images depict the Christian prayer sessions as hollow noisy and devoid of any spiritual content.

Lawino mocks the Sabbath by referring to it as the day when Christians shout until they have headache (101). This reference to the Sabbath trivialize it and shed its spiritual significance.

This paper associates successful satire with humour, criticism and human weaknesses or faults. Indeed, religious leaders are often satirized when they behave contrary to the tenets of their faith. For example, Wole Soyinka satirizes brother Jero's hypocrisy in Trials of Brother Jero. In the play, we are presented with two appearances of Jero. He is portrayed as a pious, fiery preacher who is concerned about his flock, but on the other hand, he is also dishonest, self-centred and materialistic. Tartuffe, in Jean Baptist Moliere's Tartuffe is also criticized. Madame Pemelle calls Tartufee "a saint, a man of God". She also considers him the epitome of love, gentleness and kindness. Indeed Tartuffe presents himself in these positive qualities before his benefactors. But in reality, he is a flirt and a hypocrite.

Moliere and Soyinka's criticism target religious leaders who act contrary to the expectations of their religion. Indeed, Okot also focuses on religious leaders. But in some incidents, he pours vitriol on the tenets of the Christian faith. For example, in the incident of the hunchback mentioned, Okot's intention is to criticize the concept of a single supreme creative God. He criticizes the idea using humorous language. His humour can be offensive and likely to evoke resentment rather than the pleasurable effect associated with satire.

\section{CONCLUSION}

In this study, it is evident that satire is an effective weapon in the hands of the satirist because it enables him to criticize and evoke humour at the same time. In the study, we notice that religion and religious leaders form part of Okot's major concerns. However, he concentrates on individuals whose weaknesses are stumbling blocks towards standards set by the society. Religious leaders for example, are ridiculed for failing to live according to the tenets of their religion. Using their religion as the yardstick, protestant and catholic leaders are criticized for incompetence, arrogance, bribery, pride, sexual immorality and dishonesty. 
In relation to religion, the paper concludes that Okot's satire on the tenets of the Christian religion, is not as humorous as human foibles. In the case of the tenets of the Christian religion, Okot's humorous criticism is likely to evoke disgust, rather than the acceptance associated with satire.

It can be rightly concluded that Okot's satire in this regard appears like a double-edge sword because it ridicules his victims using the tools of satire coupled with stylistic devices.

\section{REFERENCES}

Baumgartner, J. C., \& Morris, J. S (2009). The Daily Show effect: Candidate evaluations, efficacy, and American youth.American Politic Research, 34(3), 341 367.

Bruun, H. (2007). Knowledge and Reflection in Entertainment. A case study on satirical Programmes in Danish Public Service Television. 'TV entertainment: Crossmodiality and knowledge'.

Cao, X., \& Brewer, P. R. (2008). Political comedy shows and public participation in politics. International Journal of Public Opinion Research, 20(1), 90-99.

Greene, J. G. (2009). The truth, unfiltered byargument: The multimodal construction of Contemporary political satire in the Colbert Report. Thesis (M.S.) -Carleton University

Higgs, P (2012) Deconstruction and re-thinking education.South African Journal of Education 22(3) 170-176

Khalayi, R. (2014). The use of humour in socio-political commentary in Mwalimu Andrew's staffroom diary. Digital repository.Thesis (M.S) - University of Nairobi, Kenya.

Moy, P., Xenos, M. A., \& Hess, V. K. (2007). Priming effects of late-night comedy. International Journal of Public Opinion research, (18(2), 198-210.

Ogola, G. (2009). Mapping Texts: Imagining Audiences in Popular Fiction.English Studies in

Africa, 45 (2), 47-61.

Olaniyan, M. E. (2015). The effectiveness of satire as a dramatic tool for societal reformation:

EfuaSutherland's The Marriage of Anansewa, Examined. European Journal of Research and Reflection in Arts and Humanities.3(4).

P'Bitek, O. (1984). Song of Lawino and Song of Ocol. London: Heinemann.

Prior, M. (2011). News vs entertainment: How increasing media choice widen gaps in political knowledge and turnout. American Journal of Political Science, 49(3), 57592. 